\title{
Social class, non-employment, and chronic illness: continuing the inequalities in health debate
}

\author{
SARA ARBER
}

\begin{abstract}
The 1981-2 General Household Survey showed steep class gradients in limiting longstanding illness for men and women aged 20-59 that were very similar to the class gradients in mortality in the 1979-83 decennial supplement. The class gradient for women classified by their husband's occupation was stronger than that when they were classified by their own occupation. Men and women who lacked paid employment reported poorer health than the employed and were concentrated in the lower social classes. Inequalities in ill health due to class were partly caused by the higher proportion in the lower social classes who were without work. Class differences in ill health still existed, however, among the currently employed, with unskilled men reporting particularly poor health and women manual workers reporting poorer health than women in non-manual jobs. Class differences were greater for the occupationless than for the currently employed.
\end{abstract}

Thus class remains an important indicator of health inequalities despite the current high level of unemployment.

\section{Introduction}

The inverse gradient between social class and ill health is well established, and there is accumulating evidence that the health of the unemployed is poor. There has been little attempt, however, to analyse the relation among social class, state of employment, and ill health. This paper considers both men and women; women have

Stratification and Employment Group, Department of Sociology, University of Surrey, Guildford

SARA ARBER, BSC, MSC, senior lecturer in sociology been rather neglected in research on class inequalities in health and in research on unemployment and health.

Awareness of inequalities in health caused by social class increased with the publication of the report Inequalities in Health, ${ }^{1}$ which relied heavily on data on class inequalities in the mortality of men below retirement age drawn from the decennial supplement on occupational mortality. ${ }^{2}$ The main published source of data on class differences in morbidity is the General Household Survey reports, which classify married women by their husband's occupation and all other women by their own occupation, ${ }^{3}$ a "conventional" approach that is increasingly being questioned. ${ }^{46}$

The relation between health and unemployment (in men) has been the subject of lively debate over recent years ${ }^{7-10}$ but has tended to be seen as a separate issue from research evidence of inequalit: in health due to social class. ${ }^{11} 12$ These two types of inequality in health are usually treated separately rather than as an interlinked problem, though the collection of data by Wilkinson is an exception. ${ }^{13}$ This paper attempts to examine systematically the relation between the two.

Analyses of inequalities in health due to social class tend to assume that everyone has an occupation, yet the increase in unemployment and early retirement means that an increasing number of men, as well as over $40 \%$ of married women, do not have a paid job. ${ }^{14}$ Because most people at some stage do not have a job it is necessary to consider to which occupational class they should be assigned. The conventional solution for married women is to classify them in the class of another member of the household (usually their husband), but this may be inappropriate for the unemployed and the retired who are living in households in which no one works. For men their last occupation has conventionally been used as a measure of their current class on the assumption that for the retired their main occupation will have influenced the accumulation of assets and therefore their current lifestyle as well as the likelihood of receiving an occupational pension. Similarly, the last occupation of the unemployed has been assumed to relate to 
their level of assets accumulated while in paid employment, including any redundancy payment, and their likelihood of obtaining another job. These assumptions, however, may be less tenable now that nearly half of unemployed men have been without a job for over a year ${ }^{15}$ and that some young people may never have had a job.

Though the classification of the employed by their current job and the unemployed by their last job provides a nearly universal measure of class for adults, this convention may systematically influence the pattern of inequalities in health caused by class. This paper analyses, firstly, class differences in ill health for men and women, classifying women both by their own occupation and by their husband's occupation if married; secondly, the extent to which men and women without paid employment are in poorer health; thirdly, the ways in which those without employment are clustered in the lower social classes; and, fourthly, how the gradient in ill health caused by social class is influenced by the proportion of people in the lower social classes who lack paid employment.

\section{Methods}

The General Household Survey is based on a yearly nationally representative sample of about 12000 private households. ${ }^{3}$ Data from the General Household Survey for 1981 and 1982 were combined in this study to provide a larger sample for analysis and therefore more reliable estimates of the differences in ill health among the British population who were not being cared for in an institution. The response rate was $84 \%$ in 1981 and 1982 . This analysis considers the age range 20 to 59 , which covers about 28000 men and women.

The measure of occupational class used in the General Household Survey is based on 19 socioeconomic groups. ${ }^{3}$ In the General Household Survey annual reports these are usually condensed into six socioeconomic groups, which for men's occupations are broadly similar to the Registrar General's social classes. ${ }^{16}$ For women's occupations, however, there are considerable differences between the Registrar General's classes and the condensed socioeconomic groups. ${ }^{17}$ This analysis used the condensed socioeconomic groups as in the published General Household Survey reports, but divided socioeconomic group 3 into $3 \mathrm{a}$ and $3 \mathrm{~b}$. The six socioeconomic groups referred to in this paper and in the tables are thus defined as: $1=$ higher professionals; $2=$ employers and managers; $3 a=$ lower professionals; $3 b=$ supervisory and junior non-manual; $4=$ skilled manual and own account; $5=$ semiskilled manual and personal service; and $6=$ unskilled manual.

The data from the General Household Survey on self reported illness are based on people's perceptions of their ill health as well as on their willingness and ability to report it to interviewers. ${ }^{18}$ There is no research evidence of variations between social groups in their willingness to report ill health. Here I consider two measures of the state of health but focus mainly on the first, as the pattern of inequality is broadly similar for both measures. The main measure used was limiting longstanding illness. The respondent was asked, "Have you any longstanding illness, disability, or infirmity?" If the answer was yes the respondent was then asked whether it limited his or her activities in any way. ${ }^{3}$ This measure of limiting longstanding illness is described by Blaxter as a measure of the functional state of health. ${ }^{18}$ The other measure used, of subjective state of health, is based on the respondent's assessment of his or her own health over the past 12 months as being "on the whole good, fairly good, or not good."

The conventional method of comparing inequalities in mortality is to use standardised mortality ratios, which enable comparisons to be made after taking into account differences in the age structure of each occupation or class. Surprisingly researchers who have analysed morbidity using data from the General Household Survey have not standardised for differences in age structure between occupational groups. The Inequalities in Health report relied heavily on the General Household Survey for documenting class differences in morbidity but simply presented figures from published General Household Survey reports broken down into very broad age categories-namely, under 16, 16-44, 45-64, and 65 and over. ${ }^{1}$ I used the indirect method of standardisation to calculate standardised limiting longstanding illness ratios for 10 year age groups-namely, 20-29, 30-39, 40-49, and 50-59.

\section{Results}

A linear gradient between chronic ill health and occupational class was clearly evident in the data from the 1981-2 General Household Survey. Table I shows that $10 \%$ of men aged $20-59$ in higher professional occupations reported a limiting longstanding illness compared with $24 \%$ of unskilled men. For women the conventional approach, in which married women are classified by their husband's occupation and all other women are assigned to a class on the basis of their own current (or last) occupation, showed health differentials comparable with those for men: An individualistic approach, which classifies all women by their own current (or last) occupation, yielded only a slightly weaker gradient. The proportion of women who reported a limiting longstanding illness increased from $7 \%$ of the few women working in the higher professions to $20 \%$ of women in unskilled jobs. Fewer women in lower professional occupations reported limiting longstanding illness than women who were managers or employers.

Because health deteriorates with age and the average age of members of some occupational classes is higher than that in others data must be standardised to allow for differences in the age structure of classes to obtain precise comparisons of inequalities in health caused by class. Table II shows the prevalence of limiting longstanding illness expressed as standardised ratios. Higher professional men were $34 \%$ less likely and unskilled men were $55 \%$ more likely to have a limiting longstanding illness than was average for all men. For women the conventional approach gave a gradient similar to that for men, except that the standardised limiting longstanding illness ratio for women classified as unskilled was lower than for unskilled men. The gradient was not perfectly linear, women in the lower professional class having a standardised limiting longstanding illness ratio of 81 while women in the routine non-manual group had an above average ratio of 104, which is slightly higher than that for women in the skilled manual class. An individualistic approach produced a weaker class gradient than the conventional approach. Two classes deviated from the linear pattern, the prevalence of limiting longstanding illness being slightly lower among women in unskilled occupations compared with that for women in semiskilled occupations, and women who were managers or employers were more likely to report long term illness than any other non-manual group.

\section{EMPLOYMENT STATE AND ILL HEALTH}

Studies of the relation between inequalities in health and social class usually classify the unemployed by their last job. Alternatively, the jobless may be excluded entirely, but if so the resulting sample will be healthier than the overall population, as shown by the Office of Population Censuses and Surveys longitudinal study analyses of mortality. ${ }^{19}$ Studies restricted to the employed are also more representative of certain groups-for example, single women-than of other groups who are less likely to be in employment-for example, married women.

TABLE I-Number (percentage) of population aged 20-59 with limiting longstanding illness by occupational class and sex

\begin{tabular}{|c|c|c|c|c|c|c|c|c|}
\hline & \multicolumn{7}{|c|}{ Socioeconomic group } & \multirow[b]{3}{*}{ All } \\
\hline & \multicolumn{4}{|c|}{ Non-manual } & \multicolumn{3}{|c|}{ Manual } & \\
\hline & 1 & 2 & 3a & 3b & 4 & 5 & 6 & \\
\hline $\begin{array}{l}\text { Men (by own group): } \\
\text { No in group } \\
\text { No (\%) with illness }\end{array}$ & $\begin{array}{l}753 \\
73(10)\end{array}$ & $\begin{array}{l}2208 \\
258(12)\end{array}$ & $\begin{array}{l}996 \\
109(11)\end{array}$ & $\begin{array}{l}1364 \\
182(13)\end{array}$ & $\begin{array}{l}5665 \\
883(16)\end{array}$ & $\begin{array}{l}2231 \\
413(19)\end{array}$ & $\begin{array}{l}537 \\
127(24)\end{array}$ & $\begin{array}{l}13754 \\
2045(15)\end{array}$ \\
\hline $\begin{array}{l}\text { Women (by husband's group): } \\
\text { No in group } \\
\text { No (\%) with illness } \\
\text { Women (by own group): }\end{array}$ & $\begin{array}{l}650 \\
65(10)\end{array}$ & $\begin{array}{l}2187 \\
299(14)\end{array}$ & $\begin{array}{l}1202 \\
148(12)\end{array}$ & $\begin{array}{l}2233 \\
331(15)\end{array}$ & $\begin{array}{l}4755 \\
761(16)\end{array}$ & $\begin{array}{l}2465 \\
487(20)\end{array}$ & $\begin{array}{l}552 \\
126(23)\end{array}$ & $\begin{array}{r}14044 \\
2207(16)\end{array}$ \\
\hline $\begin{array}{l}\text { Women (by own group): } \\
\text { No in group } \\
\text { No (\%) with illness }\end{array}$ & $\begin{array}{l}106 \\
7(7)\end{array}$ & $\begin{array}{l}691 \\
100(15)\end{array}$ & $\begin{array}{l}1705 \\
195 \text { (11) }\end{array}$ & $\begin{array}{l}5498 \\
751(14)\end{array}$ & $\begin{array}{l}1147 \\
199 \text { (17) }\end{array}$ & $\begin{array}{l}3756 \\
703(19)\end{array}$ & $\begin{array}{l}1194 \\
241(20)\end{array}$ & $\begin{aligned} 14097 \\
2206(16)\end{aligned}$ \\
\hline
\end{tabular}

Source: General Household Survey 1981-2. ${ }^{3}$ 
In the General Household Survey, unemployed men reported having considerably worse health than the employed, especially between the ages of 30 and 39 , when the unemployed report having twice as much limiting longstanding illness (table III). The poorer health of the unemployed was evident in each age group and was greater when a measure of subjective state of health was used: more than twice as many unemployed as employed reported that their health was "not good." illness. Not surprisingly men who were economically inactive because of retirement or long term sickness had a very high prevalence of limiting illness. The employment state of women was similarly related to the prevalence of limiting chronic illness. Women who worked part time were the least likely to report chronic illness, and women working full time reported a similar prevalence of chronic illness to men in employment. Unemployed women reported a $16 \%$ higher prevalence of chronic illness

TABLE II-Standardised limiting longstanding illness ratios of population aged 20-59 by socioeconomic group and sex

\begin{tabular}{|c|c|c|c|c|c|c|c|c|}
\hline \multirow[b]{3}{*}{. } & \multicolumn{7}{|c|}{ Socioeconomic group } & \multirow[b]{3}{*}{ All } \\
\hline & $\therefore$ & \multicolumn{2}{|c|}{ Non-manual } & \multirow[b]{2}{*}{$\mathbf{3 b}$} & \multicolumn{3}{|c|}{ Manual } & \\
\hline & 1 & 2 & $3 \mathbf{a}$ & & 4 & 5 & 6 & \\
\hline \multirow{3}{*}{$\begin{array}{l}\text { Men (by own group) } \\
\text { Women: } \\
\text { By husband's group } \\
\text { By own group } \\
\text { (current or last) }\end{array}$} & 66 & 73 & 78 & 97 & 105 & 124 & 155 & 100 \\
\hline & 63 & 82 & 81 & 104 & 101 & 121 & 127 & 100 \\
\hline & $52 \star$ & 102 & 77 & 91 & 107 & 117. & 113 & 100 \\
\hline
\end{tabular}

^Expected number $<10$.

Source: General Household Survey 1981-2. ${ }^{3}$

TABLE III-Number (percentage) of population reporting limiting longstanding illness by employment state, age, and

\begin{tabular}{|c|c|c|c|c|c|}
\hline Age & Employed & Unemployed & Housewives & $\begin{array}{l}\text { Ratio of unemployed } \\
\text { to employed }\end{array}$ & $\begin{array}{c}\text { Ratio of housewives } \\
\text { to employed }\end{array}$ \\
\hline $\begin{array}{l}20-29 \\
30-39 \\
40-49 \\
50-59\end{array}$ & $\begin{array}{l}217(7) \\
342(10) \\
394(14) \\
502(19)\end{array}$ & $\begin{array}{l}57(11) \\
66(20) \\
55(23) \\
77(33)\end{array}$ & Men & $\begin{array}{l}1.51 \\
2.00 \\
1.65 \\
1.75\end{array}$ & \\
\hline Total & $11983(12)$ & $1332(19)$ & & 1.58 & \\
\hline $\begin{array}{l}20-29 \\
30-39 \\
40-49 \\
50-59\end{array}$ & $\begin{array}{l}143(7) \\
246(11) \\
324(15) \\
362(18)\end{array}$ & $\begin{array}{l}33(11) \\
27(16) \\
27(21) \\
25(23)\end{array}$ & $\begin{array}{l}\text { Women } \\
\quad 117(10) \\
197(14) \\
203(23) \\
353(32)\end{array}$ & $\begin{array}{l}1.73 \\
1.50 \\
1.42 \\
1.23\end{array}$ & $\begin{array}{l}1.48 \\
1 \cdot 31 \\
1.58 \\
1.76\end{array}$ \\
\hline Total & $8718(12)$ & $705(16)$ & $4618(19)$ & 1.29 & 1.53 \\
\hline
\end{tabular}

Source: General Household Survey 1981-2. ${ }^{3}$

Unemployment was associated less with limiting longstanding illness in women than in men. There was a clear age gradient, with $73 \%$ more young (20-29) unemployed women reporting limiting longstanding illness than employed women. The differential was smallest in the group aged over 50 , in which only $23 \%$ more unemployed women reported limiting longstanding illness than employed women. By contrast, the greatest health differential between housewives and employed women was in the 50-59 age group. Thus both housewives and unemployed women had poor health.

Table IV shows the poorer health of men and women not in employment by age standardised ratios for limiting longstanding illness. Employed men were nearly $20 \%$ less likely to report limiting chronic illness than all men, while the unemployed were over $40 \%$ more likely to report a limiting chronic

TABLE IV-Standardised limiting longstanding illness ratios of population aged 20-59 by employment state and sex

\begin{tabular}{|c|c|c|c|c|}
\hline \multirow{2}{*}{$\begin{array}{c}\text { Employment } \\
\text { state }\end{array}$} & \multicolumn{2}{|c|}{ Ratio* } & \multicolumn{2}{|c|}{ No } \\
\hline & Men & Women & Men & Women \\
\hline $\left.\begin{array}{l}\text { Full time } \\
\text { Part time }\end{array}\right\}$ & 82 & $\left.\begin{array}{l}81 \\
75\end{array}\right\}$ & 11983 & $\begin{array}{l}4831 \\
3885\end{array}$ \\
\hline Unemployed & 143 & 116 & 1332 & 705 \\
\hline Housewives & & 123 & & 4618 \\
\hline Othert & 362 & 289 & 644 & 457 \\
\hline All & 100 & 100 & 13959 & 14496 \\
\hline
\end{tabular}

«Standardised for age groups 20-29, 30-39, 40-49, and 50-59.

tIncludes retired and permanently sick and, for men, housewives.

Source: General Household Survey 1981-2. ${ }^{3}$ than all women, but the prevalence in housewives was nearly one quarter above the average. For men and women the highest prevalence of limiting longstanding illness was in those classified as other at about three times higher than the national average.

\section{EMPLOYMENT STATE AND OCCUPATIONAL CLASS}

Unemployment did not affect equally all groups in the labour market but was concentrated among manual workers, particularly among the semiskilled and unskilled. Table $\mathrm{V}$ shows these social divisions in the likelihood of unemployment. Fewer than $5 \%$ of men in socioeconomic groups 1,2 , and 3a (professionals and managers) were unemployed compared with $20 \%$ of semiskilled men and $35 \%$ of unskilled men. Thus over seven times more unskilled men than professional or managerial men did not have a job.

Class differences in women's participation in the labour force were less pronounced than those seen for men but were in the same direction, with the highest proportion employed in socioeconomic groups 1,2 , and $3 a$ and the lowest proportion in semiskilled and personal service jobs. Among socioeconomic group 5, 37\% were housewives and $7 \%$ were unemployed, proportions that were higher than in any other socioeconomic group. Thus in analyses of women's health by their own occupational class we would expect a higher prevalence of ill health among semiskilled women simply because of the high proportion who were not in paid employment, and a lower prevalence among women in professional and managerial occupations, in which over $75 \%$ were employed.

Many unskilled women (socioeconomic group 6) were working part time (table V). In fact $85 \%$ of women currently employed in unskilled occupations were working part time. This occupational class would probably have better health than the same occupational class for men because of occupational downgrading among married women who work part time. ${ }^{20}$ 


\section{EMPLOYMENT STATE AND CLASS INEQUALITIES IN ILL HEALTH}

As unemployment, early retirement, and long term sickness were concentrated among unskilled men and to a less extent among the semiskilled we would expect these occupational classes to have poorer health. Only a part of the steep class gradient for men, however, can be explained by the different proportions of each class who were not in employment, as a weak class gradient remained for men currently in work (table VI). Men who worked in upper and middle class occupations (socioeconomic groups 1, 2, and 3a) were about a third less likely to report limiting chronic illness than all men; men in junior non-manual, skilled, and semiskilled manual occupations were over $10 \%$ less likely to report chronic illness than all men; and men working in unskilled occupations had a considerably higher prevalence of long term illness. The finding that men in unskilled jobs had much poorer health than other employed men cannot be discounted as a methodological artefact, the disclaimer used to dismiss the class gradient in mortality found in the 1979-83 decennial supplement. ${ }^{21}$

Class differences in ill health were greater among the occupationless-that is, the unemployed, early retired, long term sick, and full time studentsthan among the employed-for example, the standardised limiting longstanding illness ratio varied from 158 for men last employed as managers and employers to over 240 for men who last worked in semiskilled or unskilled occupations (table VI).

Among women who worked a higher proportion in manual occupations reported limiting longstanding illness than those in non-manual jobs. Unlike for men there were no differences in ill health among women in the three more clearly among those no longer in employment than among those who were currently working.

\section{Discussion}

The General Household Survey is the most important source of data in the United Kingdom on the health of the national population, providing representative data on all of the population not cared for in institutions. The omission of those people in institutions matters little for the 20-59 age group, of whom fewer than $1 \%$ are in institutional care.

The 1981-2 General Household Survey shows a higher prevalence of limiting longstanding illness among the semiskilled and unskilled, over twice as many unskilled men reporting limiting longstanding illness as professional men. The class differences in chronic illness measured with standardised ratios (table II) are remarkably similar to the standardised mortality ratios reported in the recent decennial supplement on occupational mortality. ${ }^{21}$ Standardised mortality ratios for men varied from 66 for class I (professionals) to 165 for class V (unskilled) and for women from 69 for class I to 134 for class V. In the General Household Survey the standardised limiting longstanding illness ratios for men vary from 66 for socioeconomic

TABLE V-Employment state. Number (percentage) of population aged 20-59 by sex and own socioeconomic group

\begin{tabular}{|c|c|c|c|c|c|}
\hline & \multicolumn{4}{|c|}{ Socioeconomic group } & \multirow[b]{2}{*}{ Total } \\
\hline & 1,2 , and $3 a$ & $3 b$ and 4 & 5 & 6 & \\
\hline $\begin{array}{l}\text { Employed } \\
\text { Unemployed } \\
\text { Retired or sick }\end{array}$ & $\begin{array}{rr}3721 & (95) \\
139 & (4) \\
42 & (1)\end{array}$ & $\begin{array}{rr}6151 & (89) \\
631 & (9) \\
142 & (2)\end{array}$ & $\begin{array}{rr}1710 & (79) \\
369 & (17) \\
82 & (4)\end{array}$ & $\begin{array}{rr}333 & (65) \\
145 & (28) \\
37 & (7)\end{array}$ & $\begin{array}{r}11915 \text { (88) } \\
1284(10) \\
303\end{array}$ \\
\hline Total & $3902(100)$ & $6924(100)$ & $2161(100)$ & $515(100)$ & $13502(100)$ \\
\hline \multicolumn{6}{|c|}{ Women } \\
\hline $\begin{array}{l}\text { Employed: } \\
\text { Full time } \\
\text { Part time } \\
\text { Housewives } \\
\text { Unemployed } \\
\text { Retired or sick }\end{array}$ & $\begin{array}{rr}1237 & (50) \\
651 & (26) \\
490 & (20) \\
74 & (3) \\
30 & (1)\end{array}$ & $\begin{array}{rr}2499 & (38) \\
1564 & (24) \\
2107 & (32) \\
303 & (5) \\
121 & (2)\end{array}$ & $\begin{array}{rr}980 & (26) \\
1022 & (27) \\
1371 & (37) \\
263 & (7) \\
93 & (3)\end{array}$ & $\begin{array}{rr}114 & (10) \\
650 & (55) \\
343 & (29) \\
51 & (4) \\
35 & (3)\end{array}$ & 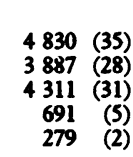 \\
\hline Total & $2482(100)$ & $6594(100)$ & $3729(100)$ & $1193(100)$ & $13998(100)$ \\
\hline
\end{tabular}

Source: General Household Survey 1981-2. ${ }^{3}$

TABLE VI-Standardised limiting longstanding illness ratios of population aged 20-59 by socioeconomic group, employment state, and sex

\begin{tabular}{|c|c|c|c|c|c|c|c|c|}
\hline \multirow{3}{*}{. } & \multicolumn{7}{|c|}{ Socioeconomic group } & \multirow[b]{3}{*}{ All } \\
\hline & \multicolumn{4}{|c|}{ Non-manual } & \multicolumn{3}{|c|}{ Manual } & \\
\hline & 1 & 2 & $3 \mathbf{a}$ & $\mathbf{3 b}$ & 4 & 5 & 6 & \\
\hline \multicolumn{9}{|l|}{ Men: } \\
\hline $\begin{array}{l}\text { Employed } \\
\text { Not in employment }\end{array}$ & $\begin{array}{l}66 \\
65^{\star}\end{array}$ & $\begin{array}{r}67 \\
158\end{array}$ & $\begin{array}{c}70 \\
181^{\star}\end{array}$ & $\begin{array}{c}85 \\
224 t\end{array}$ & $\begin{array}{r}88 \\
216\end{array}$ & $\begin{array}{r}89 \\
246\end{array}$ & $\begin{array}{l}108 \\
242\end{array}$ & $\begin{array}{r}82 \\
218\end{array}$ \\
\hline \multicolumn{9}{|l|}{ Women: } \\
\hline $\begin{array}{l}\text { Employed (own current occupation) } \\
\text { Not in employment (last occupation) }\end{array}$ & $\begin{array}{l}45 \dagger \\
83^{\star}\end{array}$ & $\begin{array}{r}82 \\
134\end{array}$ & $\begin{array}{l}72 \\
95\end{array}$ & $\begin{array}{r}72 \\
122\end{array}$ & $\begin{array}{r}87 \\
136\end{array}$ & $\begin{array}{r}86 \\
154\end{array}$ & $\begin{array}{r}85 \\
163\end{array}$ & $\begin{array}{r}78 \\
136\end{array}$ \\
\hline
\end{tabular}

*Expected number $<10$.

t10<Expected number $<20$.

Source: General Household Survey 1981-2.3

manual classes, and the only difference among women non-manual workers was that those who were employers or managers were more likely to report chronic illness than other non-manual women.

Among the $40 \%$ of women who were jobless there was a clear class gradient, from a standardised ratio of 95 for women who last worked in a semiprofessional job to 163 for women who were last employed as unskilled workers. Women who were higher professionals had a lower prevalence of chronic illness, but women who last worked as managers or employers were a third more likely to report a limiting longstanding illness than the average for all women. Thus for women inequalities in health due to class were seen group 1 (equivalent to class I) to 155 for socioeconomic group 6 (equivalent to class V) and for women from 63 for socioeconomic group 1 to 127 for socioeconomic group 6. The authors of the decennial supplement, however, were at great pains to point out that standardised mortality ratios on class "are subject to considerable bias." The main bias was said to be the "numerator/ denominator bias," in which some men are assigned to different classes at census and at death registration, which was said to occur particularly for men in social class V. Because of these biases the 
decennial supplement concluded that the social class standardised mortality ratios were unreliable and discounted the apparently widening class differential shown in 1979-83 compared with 1970-2.

Data from the General Household Survey do not suffer from any biases based on numerator/denominator inconsistencies because the data about ill health and social class are obtained at the same time from the same person. The class gradient for age standardised limiting longstanding illness that is found in the General Household Survey cannot therefore be dismissed as a methodological artefact. The remarkable similarity of the class gradient for limiting longstanding illness in the General Household Survey and for mortality in the decennial supplement suggests that the class data in the decennial supplement should not be treated with the scepticism accorded by the authors of that report.

Analysis of the General Household Survey microdata allows the conventional approach, which classifies married women by their husband's occupation, to be compared with the individualistic approach, which uses the woman's own current (or last) occupation. The conventional approach has been substantially criticised because of the implicit sexist assumptions that women are dependent on their husbands, but little empirical work has been done to compare the two approaches. The individualistic approach shows a weaker class gradient in ill health than the conventional approach (table II), and there are apparent anomalies in the gradient, such as the higher prevalence of limiting longstanding illness among semiskilled than among unskilled women and the poorer health of women working as employers or managers. Women in lower professional groups (socioeconomic group $3 \mathrm{a}$ ) report having considerably better health than women in socioeconomic groups $\mathbf{2}$ and $\mathbf{3 b}$, a difference that is hidden when married women are classified by their husbands' occupations.

The apparently better health of women working in unskilled compared with semiskilled occupations was also seen in women's mortality in the Office of Population Censuses and Surveys longitudinal study. ${ }^{23}$ Women's occupations are less likely to reflect their skills and labour market potential than men's, particularly for women who work part time. Such jobs are generally taken because they can be accommodated within childcare arrangements or school hours and are close to home. Martin and Roberts measured the extent of downward occupational mobility associated with childrearing, showing that the main factor leading to a reduction in occupational grade was taking on part time work. ${ }^{20}$ Hence the occupations of women working part time are unlikely to be an adequate measure of a woman's class position. Thus the better health of women working in unskilled rather than in semiskilled jobs is associated with the high proportion of women in unskilled jobs who work part time. The smaller class differences in health that are found when an individualistic approach is used may be one argument for retaining the conventional approach for analysing health differentials among women.

Findings from the General Household Survey that the employed are much healthier than those out of employment (tables III and IV) largely confirm the findings on mortality from the longitudinal study. ${ }^{19}$ I have also shown here the importance of using a broad definition of non-employment. Much of the research on unemployment and health has used a narrow definition of unemployment. This is increasingly problematic, because many of those defined as "early retired" and "housewives" may prefer to be employed but are unable to obtain a job. The large increase in the prevalence of long term sickness and early retirement has largely been a result of the declining labour market. ${ }^{24}$ This paper shows that the health of housewives as well as of "unemployed" women must be considered. Both groups have poorer health, and the category in which a woman places herself may be primarily a function of her age and eligibility for benefits. Housewives have considerably poorer health than employed women, yet there has been little research to explain this association or to measure the extent of "health selection" in women's participation in the labour force. ${ }^{25-27}$

Non-employment is socially structured to a remarkable degree: seven times more unskilled men are without work than professional or managerial men (table V). The differentials for women are less pronounced but still vary, from nearly half of semiskilled women to fewer than a quarter of professional or managerial women who are without paid employment.

The General Household Survey data show that low social class and non-employment are independently associated with poor health, but overlap is considerable. One of the reasons for the strong class gradients shown in the report on Inequalities in Health ${ }^{1}$ and in the decennial supplements on occupational mortality ${ }^{21}$ is that those classified in class IV or V (semiskilled or unskilled) are less likely to be employed.

This analysis confirms that, for the occupationless, social class based on the last occupation continues to determine their chance of being healthy, for both men and women. Thus the data from the General Household Survey support the use of last occupation as a measure of social class for those who lack paid employment. The key findings are that the morbidity differences between those in work and the jobless are greater than the class differences in health among those in work, for both men and women, and that the class differences in health for the jobless are much greater than the class differences in health for those in work. Thus class affects the jobless to an even greater extent than it does those in employment. In any study of health inequalities both class and employment state need to be considered, preferably together rather than separately.

I thank the Office of Population Censuses and Surveys for permission to use the General Household Survey and the Economic and Social Research Council data archive for supplying data. The Economic and Social Research Council provided support for preparing the 1981 and 1982 General Household Surveys into SPSS and SIR files (grant No H0023050), prepared by P Truscott, N Gilbert, A Dale, and S Arber. I am grateful to my colleagues Angela Dale and Nigel Gilbert, who were coresearchers on some of the work on which this paper is based, and for their helpful comments on an early draft of this paper.

\section{References}

1 Department of Health and Social Security. Inequalities in health. London: Department of Health and Social Security, 1980.

2 Office of Population Censuses and Surveys. Occupational morality 1970-72. London: HMSO,

3 Office of Population Censuses and Surveys. General household survey 1982. London: HMSO, 1984. 4 Nissel M. Women in government statistics: basic concepts and assumptions. Equal Opportunities Commission Research Bulletin 1980; No 4:5-28.

Stanworth M. Women and class analysis: a reply to John Goldthorpe. Sociology 1984;18:159-70

6 Hunt A. Some gaps and problems arising from government statistics on women at work. Equal Opporturities Commission Research Bulletin 1980; No 4:29-42.

7 Stern J. The relationship between unemployment and morbidity and mortality in Britain. Population Studies 1983;37:61-74.

8 Warr P. Twelve questions about unemployment and health. In: Roberts B, Finnegan R, Gallie D, eds. New approaches to economic life. Manchester: Manchester University Press, 1985

9 Moser KA, Fox AJ, Jones DR. Unemployment and mortality in the OPCS longitudinal study. Lancet 1984;ii:1324-9.

10 Smith R. "Bitterness, shame, emptiness, waste"; an introduction to unemployment and health. BrMed J 1985;291:1024-9.

11 Illsley R. Occupational class, selection and the production of inequalities in health. Quarterly Joumal of Social Affairs 1986;2:151-65.

12 Hart N. Inequalities in health: the individual versus the environment. Foumal of the Royal Statistical Society 1986;149:228-46.

13 Wilkinson $R$ ed. Class and health: research and longinudinal dara. London: Tavistock, 1986.

14 Beacham R. Economic activity: Britain's workforce 1971-1981. Population Trends 1984;37:6-13.

14 Beacham R. Economic activity: Britain's workforce 1971-1981. Population Trends 1984;37:6-13.

16 Central Statistical Office. Social commentary: social class. Social Trends. No 6. London: HMSO 1975.

17 Arber S, Dale A, Gilbert GN. The limitations of existing social class classifications for women. In Jacoby A, ed. The measurement of social class. Guildford: Social Research Association, 1986.

18 Blaxter M. A comparison of measures of inequality in morbidity. In: Fox AJ, ed. Cross national comparison of inequalities in health. London: Gower (in press).

19 Fox AJ, Goldblatt PO. Socio-demographic mortality differentials from the OPCS longitudinal study 1971-75. London: HMSO, 1982. [Series LS, No 1.]

20 Martin J, Roberts C. Women and employment: a lifetime perspective. London: HMSO, 1984

21 Office of Population Censuses and Surveys. Occupational mortaliny. The Registrar General's decennial supplement for Great Britain, 1979-80, 1982-83. London: HMSO, 1986.

22 Moser KA, Goldblatt PO. Mortality of women in the OPCS longitudinal study: differentials by own occupation and household and housing characteristics. London: City University, 1985. [Social Statistics Research Unit Working Paper No 26.]

23 Fox AJ, Goldblatt PO, Jones DR. Social class mortality differentials: artefact, selection, or life Fox AJ, Goldblatt PO, Jones DR. Social class mortality differentials: artefact, sel.
circumstances? In: Wilkinson R, ed. Class and health. London: Tavistock, 1986.

24 Piachaud D. Disability, retirement and unemployment of older men. Joumal of Social Policy 1986;15:145-62.

25 Nathanson C. Social roles and health status among women: the significance of employment. Social Science and Medicine 1980;14A:463-71.

26 Waldron E. Employment and women's health: an analysis of causal relationships. International Journal of Health Services 1980;10:435-54.

27 Arber S, Gilbert GN, Dale A. Paid employment and women's health: a benefit or a source of role strain? Sociology of Health and Illness 1985;7:375-400.

(Accepted 27 February 1987) 